Katarzyna Walęcka-Matyja

Uniwersytet Łódzki

Wydział Nauk o Wychowaniu

Instytut Psychologii

Zakład Psychologii Społecznej i Badań nad Rodziną

91-433 Łódź, ul. Smugowa 10/12

Agnieszka Przybylak

Akademia Pedagogiki Specjalnej im. Marii Grzegorzewskiej

Wydział Nauk Pedagogicznych

Instytut Pedagogiki Specjalnej

02-353 Warszawa, ul. Szczęśliwicka 40

\title{
Sytuacja życiowa rodzeństwa osób z niepełnosprawnością intelektualną
}

\section{Streszczenie}

Przedmiotem prezentowanych w niniejszym artykule badań było określenie sytuacji życiowej adolescentów i młodych dorosłych posiadających rodzeństwo z niepełnosprawnością intelektualną. W badaniach uwzględniono perspektywę zdrowych, młodych ludzi oraz ich rodziców. Zastosowano metodę wywiadu. Przebadano 25 osób (16 rodziców oraz 9 adolescentów) pochodzących z województwa łódzkiego. Rezultaty badawcze wyraźnie wskazują na istnienie zbliżonego obrazu życia rodzinnego u badanych adolescentów oraz młodych dorosłych i ich rodziców. Podejmowane próby zaprzeczania, umniejszania wpływu niepełnosprawności jednego z członków rodziny na cały system rodziny przy jednoczesnym idealizowaniu osoby niepełnosprawnego dziecka/rodzeństwa mogą świadczyć o przejawianiu przez badane rodziny mechanizmów obronnych.

Słowa kluczowe: niepełnosprawność, rodzeństwo, adolescencja, rodzina, rozwój.

\section{Wprowadzenie}

Rozwój refleksji humanistycznej obejmuje coraz to nowe obszary relacji międzyludzkich. Od dawna poziom etyczny cywilizacji mierzono stosunkiem 
do osób chorych, słabych, niesamodzielnych. Przychodzi czas, by podjąć opis oraz badanie obrazów określających nie tylko bezpośrednie sprzężenie zwrotne relacji opiekun - podopieczny, lecz także wszystko, co dzieje się w bliższym i dalszym otoczeniu rdzenia tematu.

Problematyka rodzin borykających się z trudnościami wynikającymi z niepełnosprawności dzieci jest szeroko podejmowana w literaturze przez wielu badaczy w Polsce i za granicą. Podnoszona tematyka najczęściej dotyczy zagadnień związanych z funkcjonowaniem dzieci z dysfunkcjami oraz rodziców znajdujących się w specyficznej, często przekraczającej ich możliwości adaptacyjne sytuacji życiowej. Niewiele natomiast uwagi poświęca się psychologicznemu położeniu pełnosprawnego dziecka w rodzinie z niepełnosprawnym rodzeństwem.

Przyjmując założenia koncepcji rodzin M. Bowena i S. Minuchina, zdrowe rodzeństwo stanowi jeden z elementów systemu rodzinnego, który jest powiązany z jego wszystkimi członkami siecią relacji międzyludzkich i decyduje o jakości funkcjonowania rodziny (za: Namysłowska, 2000). Zatem w procesie analizy psychologicznej systemu rodzinnego koniecznością jest zwrócenie uwagi na sytuację pełnosprawnego rodzeństwa dziecka przewlekle chorego oraz uwzględnianie go w planowaniu działań pomocowych. Fakt, iż powyższa problematyka nie została jeszcze w sposób dostateczny zbadana i wyjaśniona stanowił inspirację dla autorek niniejszego artykułu.

Obecność choroby przewlekłej (niepełnosprawności) jednego z członków rodziny zawsze prowadzi do szeregu zmian w systemie rodzinnym, zaburzając jego homeostazę. Wzajemne oddziaływania zachodzące między rodziną a stanem zdrowia jej członków pozwalają na wyodrębnienie dwóch głównych kierunków badań. Pierwszy kierunek badań dotyczy określenia roli rodziny w genezie i rozwoju różnych chorób. Przykład wpływu sytuacji rodzinnej na stan zdrowia członków rodziny stanowią wyniki badań empirycznych dotyczące etiologii niektórych schorzeń psychosomatycznych, a czasami także psychicznych. S. Miniuchin i jego współpracownicy wykazali, że zaburzenia w procesie komunikacji między członkami rodziny pozostają w związku z nieskutecznością leczenia dzieci chorych na cukrzycę (Miniuchin, Rosman i Baker, 1978). Udowodniono, że problemy zdrowotne nasilają się, gdy zakłóceniu ulegają relacje małżeńskie (Rostowska, 2001).

Natomiast drugi kierunek badań podejmuje problematykę związaną z wyjaśnieniem znaczenia wpływu choroby na funkcjonowanie rodziny. Czynnikiem decydującym o jakości zmian w systemie rodzinnym jest m.in. to, kogo dotyczy proces chorobowy - dziecka, matki czy ojca? Kiedy choruje dziecko rodzice doświadczają silnego stresu. Głównie u matek jest on związany przede wszystkim z lękiem o zdrowie i życie dziecka z niepełnosprawnością, ze stanami napięcia wywoływanymi przez niemożność realizowania swych zarówno 
osobistych, jak i zawodowych potrzeb, z ograniczeniami wynikającymi z nadmiaru obowiązków, a także z zaistnienia zaburzeń w przebiegu cyklu życia rodzinnego ${ }^{1}$ (Plencer, 2009). Stres rodziców niepełnosprawnych dzieci zależy także od cech samego dziecka. Znaczenie mają tu: osobowość, poziom motywacji, obecność lub brak fizycznych stygmatów, zaburzeń sensorycznych i motorycznych, problemów zdrowotnych, kondycji psychicznej, temperamentu, zachowań, wieku, płci, kolejności urodzenia niepełnosprawnego dziecka (Fisman, Wolf, Ellison, Gillis, Freeman, Szatmari, 1996).

Rodzice i dziecko dotknięte niepełnosprawnością to nie jedyne osoby w rodzinie, które doświadczają stresu oraz trudności psychicznych. Sytuacja ta wywołuje także ogromne napięcie u pełnosprawnego rodzeństwa dziecka z niepełnosprawnością. Ma ono bowiem częściej niż w innych rodzinach częsty kontakt z bólem, rozpaczą, bezradnością czy problemami różnej natury (Morrison, 1997). Wzrastająca liczba zachowań opiekuńczych ze strony matki kierowanych do chorego przewlekle dziecka powoduje, że potrzeby męża i pozostałych dzieci nie zostają w pełni zaspokajane. W konsekwencji budzi to stany niezadowolenia, napięcia, zazdrości oraz rywalizacji między rodzeństwem.

\section{Specyfika funkcjonowania zdrowego rodzeństwa osób niepełnosprawnych}

W literaturze przedmiotu można wyodrębnić zasadniczo dwa podejścia do sytuacji życia i warunków rozwoju pełnosprawnego dziecka w rodzinie z niepełnosprawnym rodzeństwem.

Niektórzy badacze wskazują, że fakt posiadania niepełnosprawnego rodzeństwa jest czynnikiem stymulującym rozwój zdrowego rodzeństwa. Umożliwia on bowiem, poprzez specyficzne doświadczenia życiowe, nabycie umiejętności i kompetencji niedostępnych dla osób żyjących w rodzinach bez osób z niepełnosprawnością. Niektórzy zdrowi bracia lub siostry stają się bardziej dojrzali pod względem społecznym, wrażliwi na potrzeby innych, bardziej samodzielni oraz deklarujący akceptację i zrozumienie dla odmienności (Pisula, 2007; Żyta, 2009). Ilustrację mogą stanowić słowa 10-letniej dziewczynki, która co wieczór gotowała obiad dla całej rodziny: „Nie sądzę, żeby ktokolwiek oczekiwał ode mnie, żebym to robiła, ale jeśli raz zrobisz coś takiego, to już się będą tego

${ }^{1}$ Badacze wskazują, że w przypadku rodzin z dzieckiem niepełnosprawnym może nie nastąpić piąta faza cyklu rodzinnego, tj. faza postprenatalna. Ma ona miejsce w czasie, gdy dzieci usamodzielniają się. Niepełnosprawność dziecka może skutkować przejściem z fazy czwartej cyklu życia rodzinnego, tj. ustabilizowanej struktury i czynnego rodzicielstwa do fazy schyłkowej, charakteryzującej się okresem emerytalnym rodziców, a kończącej się ich śmiercią (Leszkowicz-Baczyńska, 1999). 
po tobie spodziewać [...]. Prawdopodobnie byłam znacznie bardziej dojrzała, mając 9-10 lat, niż inni w tym wieku. Przejawiało się to w pilnowaniu zadanych lekcji, praniu, prasowaniu, otwieraniu własnego konta w banku... Mama po prostu nie miała na to czasu" (Rodger, Tooth, 2004, s. 59).

Jak wynika z badań, efekty i jakość relacji zachodzących między rodzeństwem stanowią istotny czynnik warunkujący wybór przyjaciół w okresie młodości, a w dalszej perspektywie partnerów życiowych. Na uwagę zasługują wyniki badań dowodzące tego, że zdrowe rodzeństwo niepełnosprawnych dzieci nie uwzględnia możliwości stworzenia związku z osobą o negatywnych postawach wobec zjawiska niepełnosprawności. Ważny z punktu widzenia psychologii rozwoju człowieka jest także proces kształtowania tożsamości, który częściowo determinuje posiadanie niepełnosprawnego rodzeństwa. Porównania z tymże rodzeństwem wspierają indywidualność oraz autonomię pełnosprawnego adolescenta (Ley, 2004).

Dokonując przeglądu literatury, można także odnaleźć liczne badania wskazujące na niedostosowanie rodzeństwa dzieci z niepełnosprawnością (Cuskelly, 1999; Sharpe, Rossiter, 2002; Vermaes, Susante, Bakel, 2012).

Rodzeństwo w normie rozwojowej często odczuwa, że rodzice (głównie matki) są nadopiekuńczy wobec chorego brata czy siostry (poświęcają mu więcej czasu i uwagi, dają prezenty), a także zbyt pobłażliwi (np. brak wymagań). Ograniczony czas na wspólne bycie ze sobą na rzecz czynności opiekuńczych wykonywanych przy dziecku z dysfunkcją w zakresie sfery intelektualnej, niedostrzeganie przez rodziców wkładu pracy w opiekę nad niepełnosprawnym rodzeństwem oraz zapominanie o potrzebach zdrowego rodzeństwa to tylko niektóre powody skutkujące poczuciem zaniedbania zdrowego rodzeństwa w normie rozwojowej przez rodziców. Długotrwały stan ignorowania zdrowego rodzeństwa może ukształtować u niego przekonanie o uprzywilejowanej pozycji niepełnosprawnego brata/siostry, a tym samym o swej mniejszej wartości w oczach rodziców. W efekcie powyższego pełnosprawne dziecko może obrażać się na rodziców i chore rodzeństwo przy jednoczesnym poczuciu winy oraz niepokoju o los wszystkich członków rodziny (Bronfman, Campis, Koocher, 1998). Kolejną z przyczyn przeżywanego napięcia przez zdrowe rodzeństwo może stanowić także brak rozmów z rodzicami na temat choroby i szczerego wyrażania uczuć przeżywanych w związku z nią (Clarke, Davies, Jenney, Glaser, Eiser, 2005).

$\mathrm{U}$ pełnosprawnego rodzeństwa $\mathrm{w}$ wyniku minimalizowania swoich potrzeb mogą występować napady gniewu ukierunkowane na niepełnosprawnego brata lub siostrę. Często skutkuje to karą ze strony rodziców. Obawa przed ostrą reakcją rodziców może prowadzić do prób zagłuszania swej złości, do zachowań, które nie należą do konstruktywnych sposobów radzenia sobie z emocjami. W dalszej perspektywie rozwojowej pełnosprawne rodzeństwo może zagłuszać inne emocje, także te przyjemne. Brak umiejętności prawidłowego wyrażania emocji oraz nabycie swej wyższości w kwestii zdrowia, siły i możliwości intelektualnych nad 
niepełnosprawnym rodzeństwem u pewnej części rodzeństwa wywołuje poczucie winy, którego konsekwencje mogą być dwojakiego rodzaju. Rodzeństwo może przyjąć postawę altruistyczną i w pełni angażować się w pomoc niepełnosprawnemu bratu czy siostrze bądź przeciwnie, można zaobserwować u niego zachowania mające na celu odizolowanie się od problemu niepełnosprawnego rodzeństwa. Ponadto pełnosprawne dzieci muszą radzić sobie ze specyfiką macierzyństwa i ojcostwa występującą $w$ rodzinach $\mathrm{z}$ dzieckiem znajdującym się poza normą rozwojową, ze zmianami zachodzącymi w rodzicach, w ich relacjach małżeńskich i rodzicielskich, co bywa zbyt dużym obciążeniem dla możliwości adaptacyjnych dorastających jednostek (Barlow, Ellard, 2006).

Obecność w rodzinie niepełnosprawnego dziecka wiąże się również z występowaniem dwóch zjawisk dotyczących pełnienia ról przez rodzeństwo w normie rozwojowej, $\mathrm{tj}$. poszerzenia ról oraz pomieszania ról.

Zjawisko poszerzenia ról odnosi się do sytuacji, kiedy rodzice oczekują od zdrowego rodzeństwa towarzyszenia choremu przewlekle bratu czy siostrze w wielu sferach aktywności, jak np. w zabawie, w nauce, w wychowaniu czy nawet $\mathrm{w}$ czynnościach pielęgnacyjnych. Jak wynika z badań głównie dziewczynki są zbytnio angażowane w opiekę i prace domowe (Eiser, 2003). Zaangażowanie wiąże się z współodpowiedzialnością za to, co dzieje się w rodzinie i pełnieniem obowiązków.

Natomiast zjawisko pomieszania ról występuje w sytuacji, gdy młodsze rodzeństwo (w normie rozwojowej) wchodzi w rolę starszego, które ze względu na ograniczenia spowodowane niepełnosprawnością nie jest w stanie wykonywać przypisanych mu obowiązków. Tego rodzaju warunki rozwoju powodują u zdrowego dziecka stan niepokoju, frustracji oraz napięcia. Warto zaznaczyć, że swe role zdrowe rodzeństwo pełni przez całe życie i od najmłodszych lat funkcjonuje z poczuciem odpowiedzialności za los drugiej osoby (Ley, 2004).

W obliczu skumulowania dużej liczby obowiązków dobrostan zdrowego rodzeństwa zostaje zagrożony. Stwierdzono, że osoby znajdujące się w tego typu sytuacji charakteryzują się wyższym poziomem lęku, mają tendencję do wycofywania się z kontaktów interpersonalnych, a także są bardziej depresyjne niż rodzeństwo osób rozwijających się prawidłowo (Fisman i in., 2000). Matki zauważają u tych dzieci więcej problemów w zachowaniu oraz spostrzegają je jako mniej skłonne do zachowań prospołecznych niż matki dzieci, których rodzeństwo jest zdrowe (Hastings, 2004). Ogólny wniosek z przeprowadzonych w tym obszarze badań pozwala twierdzić, że będące w normie rozwojowej rodzeństwo niepełnosprawnych dzieci charakteryzuje się wyższym ryzykiem wystąpienia problemów natury adaptacyjnej, zaburzeń emocjonalnych oraz trudności w nawiązywaniu prawidłowych relacji z rówieśnikami.

W związku z odmiennością funkcjonowania zdrowego rodzeństwa w rodzinie $\mathrm{z}$ dzieckiem $\mathrm{z}$ niepełnosprawnością $\mathrm{w}$ porównaniu $\mathrm{z}$ rodzinami, w których wszyscy członkowie są pełnosprawni powstaje pytanie o ocenę sytuacji rozwoju 
adolescentów w normie rozwojowej. Intensywne przemiany, które dotyczą adolescentów obejmują większość procesów rozwoju, tj. biologicznych, psychologicznych i społecznych. Dynamiczne zmiany natury fizjologicznej wpływają na stan emocjonalny młodzieży, którą naturalnie w tym wieku cechuje labilność emocjonalna. W sytuacji, gdy ktoś wygłasza niekorzystne komentarze kierowane $\mathrm{w}$ stronę osób z niepełnosprawnością intelektualną, młodzi ludzie mogą odbierać zaistniałe zdarzenie jako atak na ich samych i silnie reagować emocjonalnie. Zmiany w aspekcie poznawczym umożliwiające $\mathrm{z}$ kolei myślenie abstrakcyjne i analityczne pozwalają na podejmowanie refleksji oraz autorefleksji. W efekcie powyższego zdrowe rodzeństwo zaczyna niepokoić się o stan swojego zdrowia i o potencjalne zaburzenia, które mogą wystąpić. Wraz z dojrzewaniem pojawia się bowiem strach przed możliwymi obciążeniami genetycznymi. W percepcji rówieśników pełnosprawni adolescenci wychowywani w rodzinach z niepełnosprawnym rodzeństwem są opisywani jako osoby wrażliwe (szczególnie na kwestie niepełnosprawności), chwiejne emocjonalnie, samokrytyczne i przejawiające wysoki poziom gotowości do niesienia pomocy innym (Borzyszkowska, 1998).

\section{Problem badawczy i pytania badawcze}

Przedmiotem podjętych badań była próba określenia sytuacji życiowej adolescentów i młodych dorosłych $(\mathrm{N}=23,4$ lata), wychowywanych w rodzinach $\mathrm{z}$ rodzeństwem z niepełnosprawnością intelektualną $(\mathrm{N}=22$ lata). Przedstawione w niniejszym artykule rezultaty badawcze są efektem oceny sytuacji życiowej badanych zdrowych adolescentów oraz młodych dorosłych zarówno z ich własnej perspektywy, jak i perspektywy ich rodziców.

Na podstawie nakreślonego przedmiotu i celu eksploracji sformułowano następujące pytania badawcze:

Jak badane rodzeństwo osób z niepełnosprawnością intelektualną percypuje własne funkcjonowanie i warunki rozwoju?

Jak sytuację życiową pełnosprawnego rodzeństwa osób z niepełnosprawnością intelektualną postrzegają ich rodzice?

Problematykę badawczą doprecyzowano poprzez pytania szczegółowe:

1. Jakie specyficzne ograniczenia swej sytuacji życiowej dostrzegają badane rodzeństwa, a jakie ograniczenia owej sytuacji swych pełnosprawnych dzieci dostrzegają rodzice?

2. Jak wyglądają relacje $\mathrm{w}$ rodzinie $\mathrm{z}$ osobą niepełnosprawną intelektualnie w percepcji badanych pełnosprawnych dzieci i ich rodziców?

3. Jaką rolę w rodzinie, w ocenie własnej i rodziców, pełnią badani bracia i siostry? 
4. Jak badane osoby oceniają swoje funkcjonowanie emocjonalne, a jak postrzegają je rodzice?

5. Jak badani spostrzegają własne funkcjonowanie społeczne, a jak oceniają je rodzice?

6. Jakie oczekiwania i plany mają względem swych pełnosprawnych dzieci rodzice i jak odnoszą się one do planów dzieci?

\section{Metoda}

Uwzględniając specyfikę określonego przedmiotu i celu badań, przyjęto perspektywę badań jakościowych, z podejściem opartym na prezentacji poglądów badanych osób. Opracowano autorskie kwestionariusze wywiadu, przeznaczone osobno dla pełnosprawnego rodzeństwa i rodziców/opiekunów.

Metoda wywiadu wykorzystana została do zbadania subiektywnego postrzegania własnej sytuacji życiowej przez osoby posiadające rodzeństwo z niepełnosprawnością intelektualną oraz percypowania tej sytuacji przez rodziców tych osób. Na potrzeby poniższej pracy dokonano modyfikacji dyspozycji do wywia$\mathrm{du}^{2}$ autorstwa W. Hackenberg (1992, s. 196-199). Dyspozycje do wywiadu z rodzeństwem podzielone zostały na sześć kategorii oznaczonych literami od A do F i odnosiły się do:

- stosunku do niepełnosprawnego rodzeństwa (A),

- przeszłości (B),

- instytucjonalizacji (C),

- przyszłości (D),

- otoczenia społecznego (E),

- własnej organizacji życia (F).

W celu dostosowania metody uzyskiwania danych do interesujących autorki obszarów funkcjonowania pełnosprawnego rodzeństwa oraz kryteriów doboru grupy badawczej, pominięto w całości jedną kategorię dyspozycji, a mianowicie instytucjonalizację - odnoszącą się do kwestii umieszczenia osoby z niepełnosprawnością intelektualną w instytucji opiekuńczo-wychowawczej. Dodano natomiast dyspozycję odnoszącą się do otrzymywanego przez rodzeństwo pełnosprawne potencjalnego wsparcia ze strony specjalistycznych instytucji, np. poradnie rehabilitacyjne. Każdej kategorii przyporządkowano pytania o większej szczegółowości - w sumie sformułowano 28 dyspozycji oraz jedno pytanie otwarte, umożliwiające uzupełnienie wypowiedzi przez badanych (Aneks 1).

Część kwestionariusza wywiadu przeznaczona dla rodziców/opiekunów była podzielona na siedem obszarów, ponumerowanych cyframi od 1 do 7 oraz jedno

${ }^{2}$ Dyspozycje do wywiadu - sformułowane problemy, które stanowią tematy rozmowy badacza z osobą badaną. 
pytanie otwarte umożliwiające wyrażenie kwestii nieporuszonych w wywiadzie, a istotnych dla badanego. Każdemu obszarowi przyporządkowane zostało pytanie bądź pytania z określonej dziedziny. Wersja wywiadu według W. Hackenberg (1992) wzbogacona została o kwestie istotne dla prowadzonych badań - dodano dyspozycję odnośnie do oceny relacji między rodzeństwem oraz kwestii informowania pełnosprawnego dziecka o zagadnieniu niepełnosprawności intelektualnej (Aneks 2).

\section{Charakterystyka badanej grupy}

Podstawowe informacje odnośnie do grupy badawczej uzyskano przy wykorzystaniu autorskich Inwentarzy osobowych dla rodzeństwa i rodziców/opiekunów osób z niepełnosprawnością intelektualną.

W badaniach wzięło udział 9 rodzin (100\%) posiadających minimum jedno dziecko pełnosprawne i jedno z niepełnosprawnością intelektualną. Metodę wywiadu zastosowano wobec 16 rodziców (100\%), w tym 50\% matek i 50\% ojców oraz 9 osób (100\%) będących rodzeństwem osób z niepełnosprawnością intelektualną. Wśród badanych stanowiących grupę rodzeństwa osób niepełnosprawnych było $67 \%$ sióstr i 33\% braci. Badane rodziny w większości cechowała struktura pełna (89\%). Jedna z rodzin była monoparentalną (11\%). W przypadku $78 \%$ rodzin wywiadu udzielili oboje rodzice, w pozostałych rodzinach $(22 \%)$ badaniu poddał się tylko jeden z rodziców.

Wśród badanych rodzin $67 \%$ zamieszkiwało na terenie miasta (do 25 tys. mieszkańców), a 33\% na terenach wiejskich. Średni wiek rodziców wynosił 55 lat, w tym matek $=54,4$ lat, a ojców $=55,3$ lata (rozpiętość wieku badanych rodziców wahała się w granicach od 48 do 61 lat). Wykształcenie rodziców objętych wywiadem deklarowane było na poziomie od podstawowego do wyższego. Wykształcenie podstawowe zadeklarowało 25\% rodziców. Wykształcenie na poziomie zawodowym podało $31 \%$ osób. Wśród badanych rodziców $38 \%$ posiadało wykształcenie średnie, a jedna matka potwierdziła posiadanie wykształcenia na poziomie wyższym $(6 \%)$. Pracę zarobkową podejmowało $75 \%$ rodziców. Posiadane warunki bytowe $81 \%$ rodziców określiło jako przeciętne, zaś $19 \%$ rodziców określiło posiadane zasoby na poziomie dobrym. Żaden z rodziców nie ocenił swojej sytuacji bytowej jako bardzo dobrej, złej ani bardzo złej.

Najczęściej w objętych badaniami rodzinach było po dwoje dzieci (67\%), rzadziej troje (22\%), a w jednej tylko rodzinie liczba dzieci wynosiła 4 (11\%). Wszystkie badane rodziny zadeklarowały posiadanie wyłącznie jednego dziecka z niepełnosprawnością intelektualną. Stopień niepełnosprawności intelektualnej 
dzieci określony jako lekki cechował $45 \%$ badanych ( 4 osoby), umiarkowany dotyczył 22\% (2 osoby), zaś głęboki 33\% badanych (3 osoby). Wśród osób z niepełnosprawnością było 44\% kobiet i 56\% mężczyzn. Średni wiek osób z niepełnosprawnością intelektualną wynosił 22 lata (od 18 do 28 lat).

Wśród uczestniczącej w badaniach pełnosprawnej młodzieży i młodych dorosłych było $67 \%$ kobiet i 33\% mężczyzn o średniej wieku 23,4 lata (przedział wieku od 20 do 25 roku życia). Wszyscy badani uczęszczali do szkół. Wykonywanie pracy zarobkowej deklarowało $44 \%$ badanych, pozostali nie byli aktywni zarobkowo (56\%). Wszyscy objęci badaniem pełnosprawni adolescenci i młodzi dorośli potrafili określić stopień niepełnosprawności swego rodzeństwa.

\section{Przebieg badań}

Prowadzenie badań nad grupą rodzinną należy do jednych z trudniejszych zadań badawczych. W rodzinie bowiem występują intensywne stosunki społeczne oraz zbiegają się tu wielostronne oddziaływania, wyzwalające skomplikowane uczucia i postawy. Jednakże główne źródło trudności stanowi intymny charakter stosunków rodzinnych, które nie poddają się często obserwacji zewnętrznej, a członkowie rodziny mogą zdradzać niechęć przed ujawnianiem prywatnych, czasami wstydliwych spraw związanych z ich życiem rodzinnym. Odnosząc się empirycznie do skomplikowanych procesów życia rodzinnego, przyjęto podejście jakościowe.

Ze względu na jakościowy charakter badań oraz specyfikę problemu badawczego zdecydowano o zastosowaniu celowego doboru do próby badawczej. Z badanymi rodzinami nawiązano kontakt przez Warsztaty Terapii Zajęciowej odbywające się na terenie Ozorkowa.

Podstawowe kryterium doboru grupy pełnosprawnych młodych ludzi stanowił fakt posiadania rodzeństwa z niepełnosprawnością intelektualną przez osoby pełnosprawne, mieszczące się w przedziale wiekowym od 16 do 25 lat, czyli będące w okresie adolescencji lub wczesnej dorosłości. Osoby objęte badaniem powinny zamieszkiwać wspólnie z niepełnosprawnym rodzeństwem oraz rodzicami (obojgiem lub jednym z nich). Rodzeństwo z niepełnosprawnością intelektualną mogło być starsze lub młodsze od badanych sióstr, braci o 5 lat. Wskazanie maksymalnej różnicy wieku pomiędzy rodzeństwem miało pozwolić na wyłonienie grupy, która na podstawie wniosków z dotychczasowo prowadzonych badań cechuje się najszerszym zakresem trudności natury emocjonalnej i psychospołecznej wśród rodzeństwa osób niepełnosprawnych.

Badania przeprowadzono w okresie od stycznia do marca 2011 r., na terenie gminy Ozorków położonej w województwie łódzkim. Wywiady z poszczególnymi członkami rodziny miały charakter indywidualny, a ich efekty objęte były 
tajemnicą - badani nie znali odpowiedzi pozostałych domowników. Ze względu na specyfikę podejmowanego tematu oraz zakres badań, każdej rodzinie poświęcono minimum dwa spotkania o łącznym czasie trwania średnio 6 godzin.

\section{Wyniki badań i dyskusja nad znaczeniem wyników}

Bazując na uzyskanych odpowiedziach można skłonić się ku stwierdzeniu, iż poddane badaniu rodziny z dzieckiem z niepełnosprawnością intelektualną w większości pozytywnie oceniały swoją sytuację życiową. Pełnosprawni członkowie tych rodzin (rodzice, dzieci) nie wskazywali niepełnosprawności intelektualnej członka rodziny jako czynnika mającego istotny, negatywny wpływ na ich funkcjonowanie.

\section{System rodzinny z niepełnosprawnością w tle}

Znacząca większość badanych rodziców uznała za satysfakcjonujący poziom funkcjonowania psychospołecznego swych dzieci, zarówno z niepełnosprawnością intelektualną, jak i będących w normie intelektualnej. Matki i ojcowie, najczęściej osamotnieni w opiece nad niepełnosprawnym dzieckiem, nie zgłaszali większych trudności w zakresie wychowywania dzieci, motywując ów stan posiadanymi kompetencjami własnymi.

Rodzice deklarowali, że nie odczuli jakoby niepełnosprawność intelektualna dziecka znacząco zmieniła ich zapatrywanie na siebie, swoje poglądy, zainteresowania, plany życiowe czy też jakość relacji z współmałżonkiem, dzieckiem pełnosprawnym oraz dalszą rodziną.

Rodzice pozytywnie oceniali wiedzę swoich dzieci w temacie niepełnosprawności intelektualnej, nie przejawiali obaw o rozwój i funkcjonowanie pełnosprawnych synów/córek. W większości nie dostrzegali również wpływu niepełnosprawnego dziecka na jakość ich relacji z jego bratem/siostrą, które rozpatrywali jako pozytywne, pomimo lekkiego „ochłodzenia” w związku z wkroczeniem dzieci w okres adolescencji.

Większość badanej młodzieży i młodych dorosłych miała o sobie dobre zdanie, uważała, że jest lubiana przez swoje niepełnosprawne rodzeństwo. Osoby badane nie zgłaszały posiadania stałych obowiązków przy niepełnosprawnym rodzeństwie oraz sprecyzowanych przez rodziców oczekiwań względem ich postawy i działań na rzecz brata/siostry z niepełnosprawnością intelektualną.

Badani bracia i siostry osób niepełnosprawnych czuli się silnie związani z rodziną, pomimo to deklarowali potrzebę oddzielenia się od spraw z nią związanych poprzez kontakty z przyjaciółmi, znajomymi. Nie podejmowali się zatem działań 
mających na celu zapoznanie szerszego grona osób z tematem niepełnosprawności intelektualnej, nie rozpoczynali rozmów na ten temat ani nie uczestniczyli w spotkaniach koleżeńskich wspólnie z niepełnosprawnym rodzeństwem, które jako osoby oceniali jednak głównie w kategoriach pozytywnych.

Badani postrzegali siebie jako względnie zorientowanych w tematyce niepełnosprawności intelektualnej, nie zgłaszając przy tym chęci do pogłębiania swej wiedzy. Informacje odnośnie do stanu brata/siostry mogli pozyskiwać od rodziców (częściej od matki), ale nie czynili tego często. Niechęć do zgłębiania zagadnienia potencjalnych obciążeń genetycznych, brak rozeznania w poglądach najbliższego otoczenia odnośnie do kwestii osób z niepełnosprawnością intelektualną oraz wyraźne próby odseparowania życia towarzyskiego od rodzinnego skłaniają do stwierdzenia, że u badanych problem niepełnosprawności tylko pozornie nie istnieje. Potwierdzeniem dla tej tezy może być również wyrażony przez badanych negatywny stosunek wobec niepełnosprawności w ogóle, brak zainteresowania działalnością na rzecz osób z niepełnosprawnością intelektualną oraz nieumiejętność wskazania na cenne dla osobistego rozwoju doświadczenia, zgromadzone w wyniku wspólnego życia z osobą niepełnosprawną.

Szczególną trudność dla badanego rodzeństwa, jak i badanych rodziców stanowiło ustosunkowanie się do niepełnosprawności w ogóle, odnalezienia w niej sensu, wartości, pomimo że w odniesieniu do swego rodzeństwa/dzieci z niepełnosprawnością intelektualną potrafili oni wskazywać na liczne pozytywy. Pytanie o rozumienie, rozpatrywanie pojęcia niepełnosprawność zdziwiło badanych rodziców. Część matek i ojców stawiała opór przed podjęciem się owej definicyjnej próby, to głównie ci rodzice opisywali niepełnosprawność na wzór teoretyków, specjalistów podejmujących temat niepełnosprawności. Przykładem takiej charakterystyki może być następujące zdanie: Niepetnosprawność to zaburzenie sprawności umystowej, pewne dysfunkcje, odbieganie od norm intelektualnych, ale także zaburzona sprawność fizyczna (kobieta, lat 54).

Inna grupa matek i ojców niepełnosprawność łączyła z pojęciem choroby. Rodzice kładli wyraźny akcent na nieprzewidywalność i okrucieństwo losu: Niepetnosprawność to choroba, która nie wybiera (kobieta, lat 57); Niepetnosprawność to choroba i niesprawiedliwie, że dotyka dziecko (mężczyzna, lat 58); Niepetnosprawność to los czlowieka, na który nie bardzo mamy wpływ (mężczyzna, lat 50).

Niektórzy rodzice pojęcie niepełnosprawności opisywali poprzez jej potencjalnie negatywne skutki. Przykładem może być wypowiedź jednej z matek, która odniosła się do społecznego wymiaru szeroko pojmowanej niepełnosprawności: Niepetnosprawność to wykluczenie z normalnego życia (kobieta, lat 61).

Jeszcze inne ujęcia niepełnosprawności kumulowały w sobie spojrzenie pesymistyczne, naznaczone jednak dozą optymizmu. Czynione definicje wskazywały na liczne obciążenia, trudności wynikające z niepełnosprawności, ale i ich wartość w procesie określania swojego ,ja”: Niepetnosprawność to ogromne nieszczęście, 
wymaga silnego charakteru, aby sprostać tym trudnościom (mężczyzna, lat 56); Niepetnosprawność to nieszczęście a jednocześnie wyzwanie $w$ ksztattowaniu własnej osobowości i postawy życiowej (kobieta, lat 56).

\section{Relacje rodzinne $\mathrm{z}$ i w perspektywie}

Rodzice pozytywnie postrzegali relacje między swoimi dziećmi, deklarowali sporadyczne występowanie sytuacji trudnych wychowawczo - jako rodzice czuli się w miarę kompetentni i sprawiedliwi. Matki i ojcowie skłonni byli twierdzić, że ich niepełnosprawne dziecko miało przede wszystkim stymulujący wpływ na funkcjonowanie swego pełnosprawnego rodzeństwa - umożliwiło mu nabycie cennych umiejętności społecznych.

Relacje z rodzeństwem badani rozpatrywali jako pozytywne, a niepełnosprawne rodzeństwo oceniali, wyraźnie akcentując jego zalety. Badani czuli się ważni i lubiani przez rodzeństwo.

Młodzież i młodzi dorośli objęci badaniem opisywali swe kontakty z rodzeństwem, głównie odnosząc się do interakcji o charakterze emocjonalno-zabawowym, tylko u niektórych osób zgłaszany był aspekt świadczeniowy. Badani nie mieli przypisanych żadnych stałych obowiązków względem niepełnosprawnego rodzeństwa, swą rolę w rodzinie upatrywali w sporadycznym wspieraniu rodziców podczas zabaw z rodzeństwem czy towarzyszeniu mu podczas spacerów, wizyt u lekarza. Nie odczuwali oni żadnych form presji ze strony rodziców odnośnie do opieki nad bratem/siostrą, wskazywali na duże zaangażowanie matek i ojców w czynności wychowawcze, upatrując w ich postawie rozpatrywania niepełnosprawności jako wyzwania.

W większości badani uznawali interakcje z rodzicami za prawidłowe. Sygnalizowali poczucie nierównego traktowania ich i rodzeństwa przez rodziców, negując przy tym jakoby owa forma niesprawiedliwości rzutowała na ich stosunek do brata/siostry z niepełnosprawnością intelektualną. Badani prezentowali niską świadomość percypowania ich postaw, zachowań przez rodziców - nie czuli się przez nich faworyzowani ani deprecjonowani. Dostrzegali oni cierpienie matek i ojców w związku z niepełnosprawnością intelektualną brata/siostry, ale tylko czasami odczuwali potrzebę zrekompensowania rodzicom dodatkowych obowiązków oraz utraconych szans życiowych.

Przyszłość dzieci z niepełnosprawnością intelektualną dla badanej grupy stanowiła niejako temat tabu - rodzice wspominali o niechęci względem tego typu antycypacji, nie planowali dalszych losów swych niepełnosprawnych synów/córek. Odnośnie do planów dzieci pełnosprawnych przejawiali większą otwartość, mieli na uwadze ich potrzebę wyprowadzenia się z domu, założenia własnej rodziny. Nie zgłaszali przy tym roszczeń co do przejęcia przez dzieci opieki nad 
dzieckiem z niepełnosprawnością intelektualną. W literaturze zwraca się jednak uwagę, że ze względu na funkcjonujący w społeczeństwie polskim negatywny obraz instytucji prowadzących opiekę w placówkach dla dorosłych osób z niepełnosprawnością (głównie domy pomocy społecznej), rodzice podejmują starania umożliwiające uniknięcie umieszczenia swych niepełnosprawnych dzieci w tego typu placówkach, gdy ich już zabraknie (Krause, Żyta, Nosarzewska, 2010).

Większość badanego rodzeństwa miała sprecyzowane plany zawodowe i osobiste (założenie rodziny, posiadanie dzieci), w których - czasami nieświadomie, a czasami być może świadomie - nie uwzględniała niepełnosprawnego rodzeństwa.

\section{Swoistość położenia życiowego}

Badane rodzeństwa deklarowały świadomość odmienności swej sytuacji życiowej od doświadczeń rówieśników nieposiadających braci/sióstr z niepełnosprawnością intelektualną. Badani oceniali się przy tym wysoko, jeżeli chodzi o funkcjonowanie społeczne i emocjonalne. Nie zgłaszali dolegliwości mogących mieć podłoże psychosomatyczne. W relacjach z osobami spoza systemu rodzinnego dobrze się odnajdywali. Większość osób zadeklarowała posiadanie planów na przyszłość, chęć opuszczenia domu rodzinnego i założenia własnej rodziny. Niepełnosprawność intelektualną rodzeństwa badani nie uznawali za istotną przy wyborze ich partnera życiowego. Badani w większości nie potrafili wskazać oczekiwań rodziców względem ich przyszłości w kontekście niepełnosprawnego rodzeństwa, ani sami nie potrafili określić swej konkretnej roli w tym wymiarze.

Wywiady z rodzicami w rodzinach z dzieckiem niepełnosprawnym ukazały, że rodzice ci mają świadomość mniej korzystnej sytuacji życiowej swych pełnosprawnych dzieci w porównaniu z rówieśnikami z rodzin bez dzieci z niepełnosprawnością intelektualną. Rodzice dostrzegali swą ograniczoną dyspozycyjność względem pełnosprawnego dziecka, zaznaczając przy tym, że uczucia względem niego są równie intensywne, co w przypadku dziecka z niepełnosprawnością intelektualną. Uzyskane w tej kwestii wyniki potwierdzają badania nad psychospołecznym funkcjonowaniem rodzeństwa osób upośledzonych umysłowo w stopniu głębszym A. Żyty (2004).

Dowodem świadomości ze strony rodziców specyficznej sytuacji adolescentów i młodych dorosłych mających za brata/siostrę osobę z niepełnosprawnością intelektualną może być ich postawa cechująca się staraniami o pewną formę izolacji dziecka pełnosprawnego od niepełnosprawnego. Izolacja ta przejawiała się $\mathrm{w}$ rodzinach pod postacią nieangażowania lub małego angażowania rodzeństwa w czynności opiekuńcze nad bratem/siostrą z niepełnosprawnością intelektualną, zapewniania dużego zakresu swobód pełnosprawnemu dziecku, niepodejmowania 
starań w celu zwiększenia wiedzy rodzeństwa na temat niepełnosprawności brata/ siostry czy też w końcu nieuwzględniania lub uwzględniania w małym stopniu pełnosprawnych dzieci w aspekcie przyszłości ich rodzeństwa z niepełnosprawnością intelektualną.

\section{Niepełnosprawność a niepełnosprawność}

Badani rodzice i rodzeństwo osób z niepełnosprawnością intelektualną prezentowali bardzo zbliżony do siebie obraz życia rodzinnego. Rodzice i dzieci podobnie zapatrywali się na zagadnienie niepełnosprawności intelektualnej jednego z członków rodziny oraz jego wpływ na funkcjonowanie pozostałych osób. Zaobserwowano, że zarówno rodzice, jak i ich pełnosprawne dzieci z wyraźną trudnością i niechęcią podejmują się rozmowy na temat niepełnosprawności. Trudność ta przejawiała się nie tylko w udzielaniu przez nich odpowiedzi bardzo krótkich, zwięzłych, ale również często niemających odzwierciedlenia w rzeczywistości, powoływaniu się na idee popularyzowane przez media, bez przekonania o ich słuszności.

Bazując na zgromadzonych opracowaniach teoretycznych oraz materiale empirycznym, skłonić się można ku tezie, że w objętej badaniami grupie rodzin kluczowym problemem była nieumiejętność zmierzenia się z własnymi poglądami, postawami odnośnie do niepełnosprawności intelektualnej. Rodzice oraz rodzeństwo osób z niepełnosprawnością intelektualną podejmowali próby zaprzeczania, umniejszania wpływu niepełnosprawności jednego z członków rodziny na cały jej system i/lub idealizowali postać niepełnosprawnego dziecka. Potwierdzeniem powyższego wniosku mogą być chociażby doniesienia badaczy odnośnie do przejawianych przez rodziny z dziećmi niepełnosprawnymi mechanizmów obronnych (m.in. Kościelska, 1995; Twardowski, 2005).

Owa sytuacja mogła być spowodowana brakami w zakresie kompetencji radzenia sobie w sytuacjach trudnych. Adolescenci i młodzi dorośli objęci badaniem zadeklarowali bowiem, że nigdy nie korzystali z żadnych form bezpośredniego wsparcia dla rodzeństwa osób z niepełnosprawnością intelektualną.

Ze względu na wysoką złożoność zagadnienia funkcjonowania rodzeństwa osób z niepełnosprawnością intelektualną prezentowane wyniki badań stanowią jedynie wstęp do podejmowania dalszych kroków badawczych. Interesującą wydaje się rozbieżność pomiędzy stosunkiem rodzeństwa do brata/siostry z niepełnosprawnością intelektualną a poglądem na niepełnosprawność w ogóle. Biorąc pod uwagę, że akceptacja niepełnosprawnego dziecka, brata/siostry nie jest możliwa bez dostrzeżenia sensu w jego egzystencji, w wątpliwość poddać należy deklaracje rodziców, rodzeństwa o pozytywach życia z niepełnosprawnym dziec- 
kiem, przy jednoczesnym negowaniu przez nich jakichkolwiek wartości zjawiska niepełnosprawności.

Kolejnym, być może najważniejszym, wnioskiem jest konieczność tworzenia i wzmacniania działań pomocowych, ukierunkowanych zarówno na cały system rodziny z niepełnosprawnym dzieckiem, ze szczególnym uwzględnieniem grupy dzieci pełnosprawnych. Niektóre z proponowanych form oddziaływania psychologicznego dla wymienionych grup osób to udział w systemowej terapii rodzinnej, uczestnictwo w grupach wsparcia czy w grupach mających na celu rozwój osobisty członków poprzez kształtowanie umiejętności radzenia sobie z sytuacjami trudnymi, wzmacnianie samooceny czy edukację emocjonalną. Tego nie da się osiągnąć bez powiązania efektów nauki z instytucjami realizującymi wymienione wyżej formy oddziaływania psychologicznego.

\section{Bibliografia}

Barlow J. H., Ellard D. R., The psychosocial well-being of children with chronic disease, their parents and siblings: an overview of the research evidence base, „Child: Care, Health and Development" 2006, no 32, s. 19-31.

Borzyszkowska H., Sytuacja rodzeństwa dzieci niepetnosprawnych w rodzinie, [w:] J. Pańczyk (red.), Tożsamość polskiej pedagogiki specjalnej u progu XXI wieku, Wydawnictwo Wyższej Szkoły Pedagogiki Specjalnej im. Marii Grzegorzewskiej, Warszawa 1998, s. 147-155.

Bronfman E. T., Campis L. B., Koocher G. P., Helping Children to Cope with Traumatic Injury, „Professional Psychology: Research and Practice” 1998, no 29, s. 574-581.

Clarke S. A., Davies H., Jenney M., Glaser A., Eiser C., Parental communication and children's behaviour following diagnosis of childhood leukaemia, „Psycho-Oncology” 2005, no 14, s. 274-281.

Cuskelly M., Adjustment of siblings of children with a disability, „International Journal for the Advancement of Counselling" 1999, no 21, s. 111-124.

Eiser C., What can we learn from other illnesses?, „Journal of Cystic Fibrosis” 2003, no 2, s. 58-60.

Fisman S., Wolf L., Ellison D., Freeman T., A longitudinal study of siblings of children with chronic disabilities, „Canadian Journal of Psychiatry” 2000, no 45 (4), s. 369-75.

Fisman S., Wolf L., Ellison D., Gillis B., Freeman T., Szatmari P., Risk and Protective Factors Affecting with Adjustment of siblings of children with chronic disabilities, ,Journal of American Academy of Child \& Adolescent Psychiatry" 1996, no 35, s. 1532-1541.

Hackenberg W., Geschwister behinderter Kinder im Jugendalter - Probleme und Verarbeitunsformen, Edition Marhold, Berlin 1992, s. 196-198.

Hastings R. P., Beck A., Practitioner review: Stress intervention for parents of children with intellectual disabilities, ,Journal of Child Psychology and Psychiatry” 2004, no 45, s. 1338-1349.

Kościelska M., Oblicza upośledzenia, Wydawnictwo Naukowe PWN, Warszawa 1995, s. 229.

Krause A., Żyta A., Nosarzewska S., Normalizacja środowiska spolecznego osób z niepetnosprawnością intelektualna, Wydawnictwo Edukacyjne „AKAPIT”, Toruń 2010, s. 188. 
Leszkowicz-Baczyńska Ż., Rodzina z dzieckiem upośledzonym umysłowo. Socjologiczne studium realizacji funkcji opiekuńczo-zabezpieczającej, Lubuskie Towarzystwo Naukowe, Zielona Góra 1999, s. 254.

Ley K., Rodzeństwo - miłość, nienawiść, solidarność, Instytut Wydawniczy PAX, Warszawa 2004, S. 183.

Minuchin S., Rosman B. L., Baker L., Psychosomatic Families, Harvard University Press, Mass. 1978, s. 68.

Morrison L., Stress and siblings, „Paediatric Nursing” 1997, no 9, s. 26-27.

Namysłowska I., Terapia rodzin, Wydawnictwo: Instytut Psychiatrii i Neurologii, Warszawa 2000, s. 27.

Oleszkowicz A., Senejko A., Dorastanie, [w:] J. Trempała (red.), Psychologia rozwoju człowieka. Podręcznik akademicki, Wydawnictwo Naukowe PWN, Warszawa 2011, s. 259-283.

Pisula E., Rodzice $i$ rodzeństwo z zaburzeniami rozwoju, Wydawnictwo Uniwersytetu Warszawskiego, Warszawa 2007, s. 202.

Plencler S., Lęk rodziców wychowujących dziecko z niepetnosprawnościq intelektualna, [w:] Cz. Kosakowski i in. (red.), Relacje i doświadczenia społeczne osób z niepetnosprawnościa, Wydawnictwo Edukacyjne „AKAPIT', Torun-Olsztyn 2009, s. 207-211.

Sharpe D., Rossiter L., Siblings of Children with a Chronic Illness: A Meta-Analysis, „Journal of Pediatric Psychology" 2002, no 8, s. 699-710.

Rodger S., Tooth L., Adult siblings' perceptions of family life and loss: A pilot case study, „Journal of Developmental and Physical Disabilities" 2004, no 16 (1), s. 53-71.

Rostowska T., Konflikt międzypokoleniowy w rodzinie: analiza psychologiczna, Wydawnictwo Uniwersytetu Łódzkiego, Łódź 2001, s. 56.

Vermaes I. R., Susante A. M., Bakel H. J., Psychological Functioning of Siblings in Families of Children with Chronic Health Conditions: A Meta-Analysis, „Journal of Pediatric Psychology” 2012, no 37, s. 166-184.

Twardowski A., Sytuacja rodzin dzieci niepetnosprawnych, [w:] I. Obuchowska (red.), Dziecko niepetnosprawne w rodzinie, WSiP, Warszawa 2005, s. 18-54.

Żyta A., Rodzeństwo z głębsza niepetnosprawnością intelektualna, Oficyna Wydawnicza „Impuls”, Kraków 2004, s. 225.

Żyta A., Badania nad rodzeństwem osób z niepetnosprawnościa intelektualna w perspektywie zmian - przeszłość, teraźniejszość, przyszłość, [w:] M. Bielska-Łach (red.), Pedagogika specjalna: różne poszukiwania - wspólna misja, Wydawnictwo Akademii Pedagogiki Specjalnej im. Marii Grzegorzewskiej, Warszawa 2009, s. 372-382. 


\section{Aneks 1}

Dyspozycje do wywiadu z adolescentem posiadającym brata/siostrę upośledzoną umysłowo autorstwa W. Hackenberg (1992, s. 196-198) (po modyfikacji).

A. Stosunek do niepełnosprawnego rodzeństwa

(U. - imię upośledzonego(-ej) umysłowo brata/siostry)

1. Opisz proszę, jakim człowiekiem jest U. (wygląd, trudności, umiejętność porozumiewania się, samodzielność, zachowanie, widoczność niepełnosprawności).

2. Jaki masz stosunek do U.?

Co szczególnie lubisz w U., jakie pozytywne cechy ma U.?

Co szczególnie przeszkadza Ci w U., jakie negatywne cechy ma U.?

3. Jak U. postrzega samego siebie?

Dostrzega, że jest niepełnosprawny? Co o tym sądzi?

Jakie U. ma odczucia wobec Ciebie?

4. Czy jest coś, w czym Ty i U. jesteście podobni?

5. Czy macie ze sobą częsty kontakt?

Co razem robicie?

Czy masz stałe, regularne obowiązki w zakresie opieki nad U.?

Czy U. Cię słucha? robisz?

Czy zdarza Ci się czasami być prawdziwie zdenerwowanym na U.? Co wtedy

B. Retrospekcja (przeszłość)

6. Kiedy i jak dowiedziałeś się o upośledzeniu umysłowym?

Co wiesz o upośledzeniu umysłowym - jak do niego dochodzi?

Czy zadawałeś dużo pytań w tym zakresie? Z kim mogłeś o tym porozmawiać?

Czy zdarzało się, że rodzice nie chcieli o tym z Tobą rozmawiać?

7. Co w przeszłości znaczyło dla Ciebie posiadanie upośledzonego umysłowo rodzeństwa?

Czy żyliście ze sobą w zgodzie? O co się kłóciliście?

Jakie miałeś obowiązki w zakresie opieki nad U.?

Czy musiałeś z czegoś rezygnować z powodu niepełnosprawności U.? Jeśli tak, to $\mathrm{z}$ czego?

Czy doświadczyłeś pozytywów ze względu na U.?

Czy nauczyłeś się czegoś od U.?

8. Czy Twoi rodzice traktowali Ciebie i U. tak samo?

Czy miałeś w przeszłości wrażenie, że U. jest ulubieńcem rodziców? (a teraz?)

Czy rodzice pozytywnie reagowali na to, że intensywnie zajmowałeś się, opiekowałeś się U.? Jak reagowali, kiedy nie miałeś na to ochoty?

9. Czy Twoi rodzice bardzo cierpieli z powodu niepełnosprawności U.? Czy musiałeś ich pocieszać? 
Czy było coś, czym mogłeś wynagrodzić swoim rodzicom rozczarowanie związane z niepełnosprawnością U.?

Jak postrzegasz znaczenie niepełnosprawności U. w życiu Twojej matki?

Jak postrzegasz znaczenie niepełnosprawności U. w życiu Twojego ojca?

C. Przyszłość

12. Opisz proszę, jak widzisz życie U. w przyszłości?

13. Jaką rolę będziesz odgrywał w życiu U.?

Czego oczekują od Ciebie Twoi rodzice?

D. Środowisko (otoczenie społeczne)

14. Czy rozmawiasz ze swoimi przyjaciółmi o U.? Co im opowiadasz?

Jakie masz w związku z tym doświadczenia? Czy doświadczyłeś czegoś negatywnego?

15. Czy możesz w niezakłócony sposób spędzać czas w domu z przyjaciółmi?

Czy zabierasz ze sobą U., kiedy odwiedzasz przyjaciół?

Czy zdarzyło się już, że Twoi nowi przyjaciele lub znajomi przejawiali uprzedzenia wobec niepełnosprawnych? Co w takiej sytuacji robiłeś?

16. Które doświadczenia wykorzystałeś w szkole?

17. Czy Twoi nauczyciele i koledzy z klasy posiadają wiedzę na temat upośledzenia umysłowego? Co o tym sądzą?

Twoje poglądy na temat upośledzenia umysłowego różnią się od zapatrywania Twoich kolegów ze szkoły?

18. Czy wychodzisz z U. w miejsca publiczne (np. na zakupy, imprezy)?

Jakie zdobyłeś w tym względzie doświadczenia?

Jak reagujesz na trudności? Co przy tym odczuwasz?

19. Czy masz kontakt z innymi osobami niepełnosprawnymi?

Co on dla Ciebie znaczy?

20. Czy kiedykolwiek korzystałeś ze form wsparcia dla rodzeństwa osób upośledzonych umysłowo?

E. Własna organizacja życia

21. Czy masz stałego przyjaciela/przyjaciółkę?

Czy wie on/ona o U.? Jak zareagował/a na informacje o niepełnosprawności? Opowiedziałeś o tym? Czy uważasz, że trudno jest znaleźć partnera, kiedy ma się niepełnosprawne rodzeństwo?

22. Czy chciałbyś w przyszłości założyć rodzinę?

Czy myślałeś już o tym, co będzie, jeśli Twoje dziecko też będzie upośledzone umysłowo? (Obawiasz się tego?)

Czy poinformowano Cię w kwestii ewentualnego obciążenia genetycznego? Chciałbyś poradzić się kogoś $\mathrm{w}$ tej sprawie?

23. Czy masz już plany związane z przyszłym zawodem? (Czy miała na nie wpływ niepełnosprawność U.?) Czy zastanawiałeś się już nad tym, aby zawodowo zajmować się upośledzonymi umysłowo dziećmi?

24. Jak radzisz sobie w szkole/pracy? 
25. Co robisz w wolnym czasie?

26. Czy jesteś jeszcze silnie, mocno związany z domem rodzinnym?

Ile posiadasz wolności, swobody?

Zastanawiałeś się już nad wyprowadzeniem się z domu? Kiedy i dokąd planujesz się wyprowadzić?

27. Czy jesteś z siebie zadowolony? Co w sobie lubisz?

Co $\mathrm{Ci}$ w sobie przeszkadza, z czego nie jesteś zadowolony?

Jak sądzisz, co Twoi rodzice w Tobie lubią, cenią?

Co się im w Tobie nie podoba?

Czujesz się zdrowy i spokojny (zrównoważony)? (lęki, problemy ze snem, nerwowość)

28. Czy zastanawiasz się czasami nad sensem życia?

Czy znalazłeś już cele swojego życia?

Czy widzisz sens w niepełnosprawności?

Czy religia odgrywa ważną rolę w Twoim życiu?

29. Jaki wpływ na Ciebie, Twój rozwój miało wspólne życie z U.?

Czy jest jeszcze coś ważnego, o czym nie rozmawialiśmy? 


\section{Aneks 2}

Dyspozycje do wywiadu z rodzicami/opiekunami badanego adolescenta autorstwa W. Hackenberg (1992, s. 196-198) (po modyfikacji).

(U. - imię upośledzonego umysłowo dziecka, P. - imię zdrowego rodzeństwa)

1. Jak się ma U.? (bardzo dobrze, dobrze, przeciętnie, źle, bardzo źle)

Jakie ma obecnie trudności?

Jak wygląda przebieg dnia U., jakie formy opieki są konieczne?

Jak te zadania dzielone są między członków rodziny i pozostałe osoby z najbliższego otoczenia (małżonek, rodzeństwo, teściowie, dalsza rodzina, przyjaciele, inni)?

Czy podział ten daje Panu/Pani zadowolenie? (układ bardzo dobry, dobry, zadawalający, zły, bardzo zły)

2. Pod jakim względem niepełnosprawność wpłynęła na osobisty rozwój zdrowego rodzeństwa? (Pod jakim względem pozytywnie, negatywnie?)

Jak niepełnosprawność dziecka wpłynęła na Pana/Pani relację z jego zdrowym rodzeństwem?

Czy niepełnosprawność miała wpływ na rozwój Pana/Pani zainteresowań i planów na przyszłość? Na rozwój Pan/Pani umiejętności interpersonalnych? „Karierę” szkolną?

Czy niepokoi się Pan/Pani obecnie o rozwój R.?

3. Jak radzi sobie Pan/Pani wychowawczo ze specyficznymi dla rodzeństwa sytuacjami?

Z kłótnią? Z zazdrością? Z obowiązkami opiekuńczymi?

4. Jakie ma Pan/Pani plany na przyszłość dla U.?

Jaką rolę odgrywa w nich P.? Jak zapatruje się Pan/Pani na sytuację, że P. wyprowadzi się z domu?

5. Co niepełnosprawność oznacza w Pana/Pani życiu?

Co się dla Pana/Pani zmieniło? Jak się Pan/Pani zmienił/zmieniła?

Czy dostrzegacie Pan/Pani sens w niepełnosprawności?

Czy religia odgrywa istotną rolę w Pana/Pani życiu?

6. Czy niepełnosprawność wpłynęła na Pana/Pani związek? Jak dalece?

Jak Pana/Pani zdaniem partner (małżonek) postrzega kwestię niepełnosprawności?

Jak jest, gdy idzie Pan/Pani z U. w miejsce publiczne?

Jakie ma Pan/Pani doświadczenia z tym związane?

Jak reaguje Pan/Pani na pojawiające się trudności?

7. Jakie ma Pan/Pani doświadczenia z krewnymi, przyjaciółmi, znajomymi?

8. Czy, a jeśli tak, to kiedy i w jaki sposób poinformował Pan/Pani rodzeństwo U. o jego upośledzeniu?

9. Jak ocenia Pan/Pani wiedzę P. na temat stanu U., jego upośledzenia?

Czy jest jeszcze coś ważnego, o czym nie rozmawialiśmy? 